\title{
Analytical Instrumentation Techniques of FT-IR, XRD, SEM, and EDX for Adsorption Methods of $\mathrm{Ni}^{2+}$ lons onto Low Cost Adsorbent
}

\author{
AJITHKUMAR M and ARIVOLI S* \\ Department of Chemistry, Poompuhar College(AU),(Affiliated to Bharathidasan \\ University), Melaiyur-609107, Tamilnadu, India. \\ *Corresponding author E-Mail: arivu6363@gmail.com \\ http://dx.doi.org/10.13005/ojc/370608
}

(Received: November 22, 2021; Accepted: December 23, 2021)

ABSTRACT

In present investigate the possible removal of $\mathrm{Ni}^{2+}$ ions from aqueous solution by using lowcost Hygrophila auriculata activated nano carbon (HA-ANC) as an adsorbent. The activated nano carbon had been prepared from Hygrophila auriculata stem waste as well; the raw material was carbonized with con. $\mathrm{H}_{2} \mathrm{SO}_{4}$ and activated by thermal action. Batch experiments were performed in order to calculate the percentage removal of $\mathrm{Ni}^{2+}$ ions for $90.737 \%$ at $60^{\circ} \mathrm{C}$. The properties of treated carbon and untreated carbon are compared using instrumental techniques such as FT-IR, XRD, SEM and EDX, which confirms $\mathrm{Ni}^{2+}$ ions adsorption onto HA-ANC. FT-IR showed that the surface of HA-ANC had more oxygen containing functional groups which enhanced the adsorption of $\mathrm{Ni}^{2+}$. XRD showed the nature of adsorbent, SEM images implies morphological deviance of before and after adsorption of $\mathrm{Ni}^{2+}$ onto $\mathrm{HA}-\mathrm{ANC}$ and EDX showed that the $\mathrm{C}$ content of $\mathrm{HA}-\mathrm{ANC}$ were higher than that of $\mathrm{Ni}^{2+} / \mathrm{HA}-\mathrm{ANC}$.

Keywords: Adsorption, Hygrophila auriculata activated nano carbon (HA-ANC), Batch method, $\mathrm{Ni}^{2+}$ ions, FT-IR, XRD, SEM, EDX.

\section{INTRODUCTION}

Pollution of heavy metals has attracted global attention due to their toxicity, hard decay and accumulation in organisms. Heavy metals accumulate in the tissues of various living organisms and as a result attach to the food chain, affecting humans, posing a health risk $^{1-3}$. Therefore, the treatment of wastewater polluted by heavy metals is an important environmental concern. Ion exchange, solvent extraction, chemical precipitation, ultra-filtration, reverse osmosis, electro dialysis and adsorption are the traditional methods for removing heavy metal ions from polluted water ${ }^{4-6}$. However, absorption is considered to be one of the most popular methods for removing heavy metals from wastewater due to its low cost, in effect, biodegradability, ease of design and high removal efficiency. There are many absorbent materials available, but activated carbon is used to remove heavy metals by the adsorption method because activated carbon has a numerous pores and a large surface area ${ }^{7,8}$.

This is an Open Access article licensed under a Creative Commons license: Attribution 4.0 International (CC- BY). Published by Oriental Scientific Publishing Company @ 2018 
The literary study shows that no work has been done on Hygrophila auriculata activated nano carbon (HA-ANC) as an adsorbent, as well as low cost and high abundance. Therefore this study focused on the removal of $\mathrm{Ni}^{2+}$ ions from the aqueous solution using the HA-ANC by batch adsorption method.

\section{MATERIALS AND METHODS}

\section{Chemicals}

Analytical reagent grade chemicals were used. Stock $\mathrm{Ni}^{2+}$ ion solution (1000ppm) was prepared by dissolving required amount of $\mathrm{NiSO}_{4} \cdot 6 \mathrm{H}_{2} \mathrm{O}$ in $1000 \mathrm{~mL}$ of double distilled water. Working standards were prepared by diluting the stock solution of $\mathrm{Ni}^{2+}$ ions using double distilled water. The ionic solutions of $0.1 \mathrm{M} \mathrm{HCl}$ and $0.1 \mathrm{MNaOH}$ were made for to alter the solution $\mathrm{pH}$.

\section{Procedure for adsorbent preparation and activation}

The Hygrophila auriculata stem waste was obtained from the agricultural sites near at Poompuhar, Mayiladuthurai district, Tamilnadu, India. The stem was cut into small pieces, dried in the absence of sunlight and treated with concentrated $\mathrm{H}_{2} \mathrm{SO}_{4}$ in W/V ratio. The carbonized material washed away by double distilled water until it becomes neutral one and dried further inside the hot air oven at $110^{\circ} \mathrm{C}$ for 24 hours. The carbon was activated by using muffle furnace at $1000^{\circ} \mathrm{C}$ for $6 \mathrm{~h}$ and the activated carbon (HA-ANC) was powdered well and stored in desiccators in order to perform the experiment ${ }^{9}$.

\section{Batch adsorption method}

The batch experiments ${ }^{10}$ for $\mathrm{Ni}^{2+}$ ions removal was determined under various initial $\mathrm{pH}$ like $3,4,5,6,7,8$ and 9 besides temperature ranges from 30 to $60^{\circ} \mathrm{C}$ at an initial $\mathrm{Ni}^{2+}$ ion solution concentration was varied from 10 to $50 \mathrm{ppm}$ with different adsorbent doses and different time intervals such as 15, 30, 45, and 60 minutes. The effect of initial $\mathrm{Ni}^{2+}$ ions concentrations was investigated by using $25 \mathrm{mg}$ biomass, initial $\mathrm{pH} 6$ and volume of $\mathrm{Ni}^{2+}$ ion solution $50 \mathrm{~mL}$ are constant but varied initial $\mathrm{Ni}^{2+}$ concentrations at room temperature $\left(30^{\circ} \mathrm{C}\right)$. The $\mathrm{Ni}^{2+}$ ion solution samples were collected after 60 min of shaking then centrifuged at $120 \mathrm{rpm}$, the filtrate was analyzed. The unadsorbed $\mathrm{Ni}^{2+}$ ions were measured by using UV-Visible spectrophotometer. The removal percentage and amount of $\mathrm{Ni}^{2+}$ ions adsorption were calculated using equation 1 and equation 2 correspondingly.

Mass balance Relationship equation Eq. No.

Removal percentage $\% R=\left(\frac{C_{0}-C_{e}}{C_{0}}\right) \times 100$

Amount of adsorption $q_{e}=v \times \frac{\left(C_{0}-C_{e}\right)}{w}$

Where, \%R is the percentage of removal, $q_{e}$ is the amount of adsorbed $\mathrm{Ni}^{2+}$ ions per unit quantity of adsorbent at equilibrium time $\left(\mathrm{mg} \mathrm{g}^{-1}\right), \mathrm{C}_{0}$ and $\mathrm{C}_{\mathrm{e}}$ are the initial and actual concentration (ppm) of $\mathrm{Ni}^{2+}$ ion solutions at equilibrium time, respectively. The $\mathrm{V}$ is the volume of the $\mathrm{Ni}^{2+}$ ion solution $(\mathrm{L})$, ' $\mathrm{W}$ ' is the weight of the HA-ANC (g).

\section{Analytical tools for $\mathrm{HA}-\mathrm{ANC}$ and $\mathrm{Ni}^{2+} / \mathrm{HA}-\mathrm{ANC}$}

The determination of surface area, volume and diameter of pores for HA-ANC, BET-BJH methods were used. The FT-IR spectrum is an important tool to study the changes infrequency due to the interaction between adsorbent and adsorbate. The XRD pattern confirms the nature of the adsorbent as well as adsorption of $\mathrm{Ni}^{2+}$ ions onto HA-ANC in order to changes of $2 \theta$ values. SEM is a substantial tool to evaluate the morphological features and surface characteristics of the fresh adsorbent and treated adsorbent materials and also EDX study gives details about the element compositions ${ }^{11,12}$.

\section{RESULTS AND DISCUSSIONS}

The equilibrium data was calculated with the help of batch methodology it's incorporated some of the effective parameters such as contact time, solution $\mathrm{pH}$, adsorbent dose, temperature ${ }^{13}$. The data was given in Table 1, the result says that the nature of effectiveness of Hygrophila auriculata activated nano carbon (HA-ANC), which indicates the amount of adsorbed $\mathrm{Ni}^{2+}$ ions onto $\mathrm{HA}-\mathrm{ANC}$ increased with increasing temperature. The removal was high $(90.737 \%)$ at $60^{\circ} \mathrm{C}$ it's also declared the removal of $\mathrm{Ni}^{2+}$ ions onto adsorbent favored in elevation of temperature as well as low concentration of $\mathrm{Ni}^{2+}$ ion solution by $25 \mathrm{mg}$ of adsorbent. 
Table 1: Equilibrium Data for the Adsorption of Ni2+ ions onto HA-ANC

\begin{tabular}{|c|c|c|c|c|c|c|c|c|c|c|c|c|}
\hline \multirow[t]{2}{*}{$\mathrm{C}_{0}$} & \multicolumn{4}{|c|}{$\mathrm{C}_{\mathrm{e}}(\mathrm{Mg} / \mathrm{L})$} & \multicolumn{3}{|c|}{$q_{e}(M g / L)$} & \multicolumn{5}{|c|}{ Removal\% } \\
\hline & $30^{\circ} \mathrm{C}$ & $40^{\circ} \mathrm{C}$ & $50^{\circ} \mathrm{C}$ & $60^{\circ} \mathrm{C}$ & $30^{\circ} \mathrm{C}$ & $40^{\circ} \mathrm{C}$ & $50^{\circ} \mathrm{C}$ & $60^{\circ} \mathrm{C}$ & $30^{\circ} \mathrm{C}$ & $40^{\circ} \mathrm{C}$ & $50^{\circ} \mathrm{C}$ & $60^{\circ} \mathrm{C}$ \\
\hline 10 & 1.804 & 1.463 & 0.976 & 0.926 & 16.393 & 17.075 & 18.048 & 18.147 & 81.963 & 85.375 & 90.238 & 90.737 \\
\hline 20 & 5.363 & 4.877 & 4.408 & 3.414 & 29.275 & 30.246 & 31.184 & 33.173 & 73.188 & 75.614 & 77.960 & 82.932 \\
\hline 30 & 11.149 & 10.630 & 9.263 & 8.582 & 37.702 & 38.741 & 41.475 & 42.836 & 62.836 & 64.568 & 69.125 & 71.393 \\
\hline 40 & 17.103 & 15.641 & 14.837 & 13.917 & 45.793 & 48.718 & 50.327 & 52.166 & 57.241 & 60.897 & 62.908 & 65.208 \\
\hline 50 & 25.350 & 24.471 & 23.931 & 22.510 & 49.300 & 51.059 & 52.139 & 54.981 & 49.300 & 51.059 & 52.139 & 54.981 \\
\hline
\end{tabular}

According to the BET-BJH method, the surface area, volume and diameter of pores was obtained as $90.067 \mathrm{~m}^{2} / \mathrm{g}, 0.115 \mathrm{cc} / \mathrm{g}$ and 3.520nm, respectively.

Fourier transform infrared was used to determine the changes of vibration frequency in the functional groups of the adsorbent due to $\mathrm{Ni}^{2+}$ ions adsorption. The FT-IR spectrum within $500-4000 \mathrm{~cm}^{-1}$ for the HA-ANC before and after the adsorption of $\mathrm{Ni}^{2+}$ is shown in order to Fig. 1 and Fig. 2. The peak point of frequency; 2500 to 4000 $\mathrm{cm}^{-1}$ indicates the single bonds $(\mathrm{C}-\mathrm{H}, \mathrm{O}-\mathrm{H}, \mathrm{N}-\mathrm{H})$, 2000 to $2500 \mathrm{~cm}^{-1}$ indicates the triple bonds $(\mathrm{C} \equiv \mathrm{C}$, $\mathrm{C} \equiv \mathrm{N}), 1500$ to $2000 \mathrm{~cm}^{-1}$ indicates the double bonds $(\mathrm{C}=\mathrm{C}, \mathrm{C}=\mathrm{N}, \mathrm{C}=\mathrm{O})$ and 500 to $1500 \mathrm{~cm}^{-1}$ indicates fingerprint region. The FT-IR spectrum of HA-ANC indicates that there is remarkable change in the peaks at $2997.49 \mathrm{~cm}^{-1}, 2888.47 \mathrm{~cm}^{-1}, 1860.25 \mathrm{~cm}^{-1}$, $1560.72 \mathrm{~cm}^{-1}, 1184.19 \mathrm{~cm}^{-1}, 1123.42 \mathrm{~cm}^{-1}, 1035.85$ $\mathrm{cm}^{-1}, 795.09 \mathrm{~cm}^{-1}$, and $525.96 \mathrm{~cm}^{-1}$ respectively which it can be due to $\mathrm{Ni}^{2+}$ binding with functional groups adsorbent. The formation of new peaks, demolition of old peaks and higher to lower as well as lower to higher shifting of peaks were reason for that $\mathrm{HA}-\mathrm{ANC}$ adsorbed with $\mathrm{Ni}^{2+}$ ions ${ }^{14-16}$.

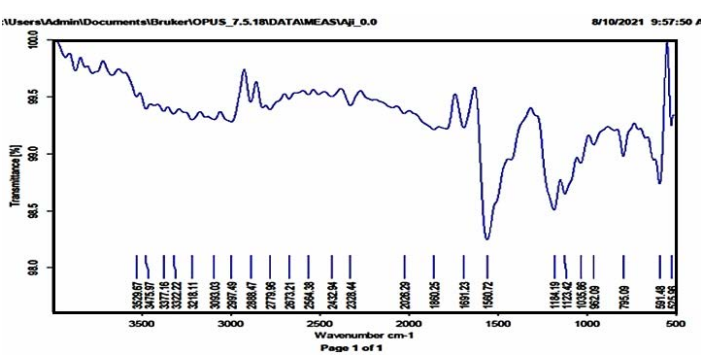

Fig. 1. FT-IR for HA-ANC

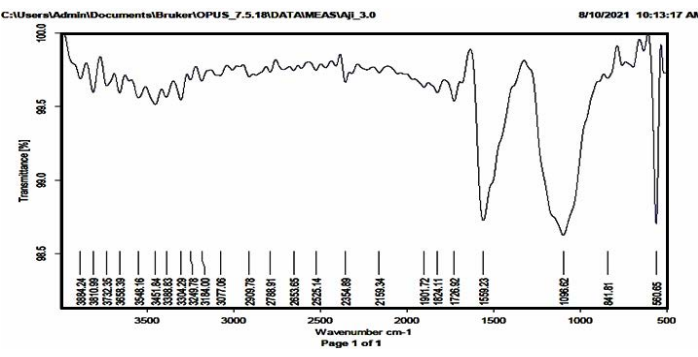

Fig. 2. FT-IR for $\mathrm{Ni}^{2+} / \mathrm{HA}-\mathrm{ANC}$
The result of XRD diffractogram for $\mathrm{HA}$ ANC (Fig. 3) revealed that the Hygrophila auriculata activated nano carbon is crystalline in nature and resembles the graphite structure ${ }^{17-19}$. After adsorption of $\mathrm{Ni}^{2+}$ ions (Fig. 4) the surface of adsorbent was disturbed this one leads to new theta values, $\mathrm{HA}-\mathrm{ANC}$ given in Table 2 and $\mathrm{Ni}^{2+} / \mathrm{HA}-\mathrm{ANC}$ given in Table 3 respectively.

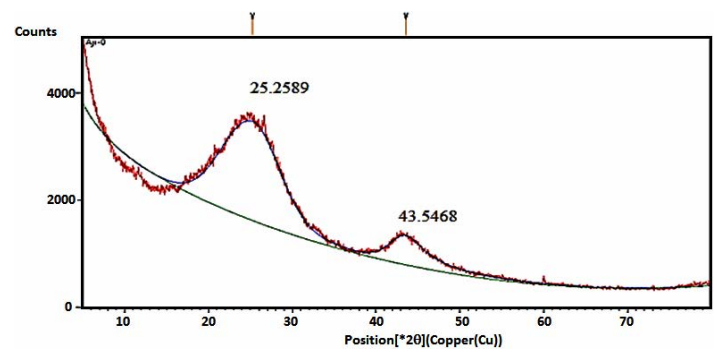

Fig. 3. XRD for HA-ANC

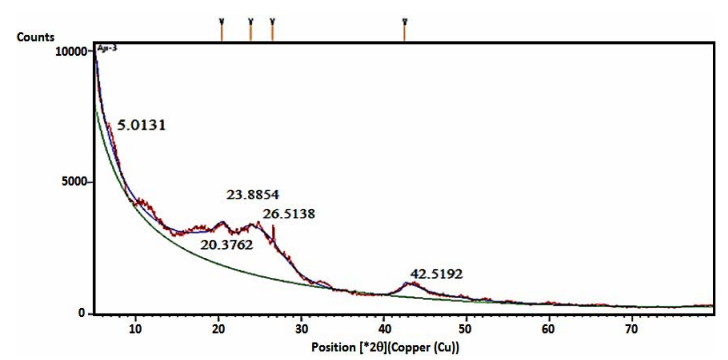

Fig. 4. XRD for $\mathrm{Ni}^{2+} / \mathrm{HA}-\mathrm{ANC}$

Table 2: XRD measurements of HA-ANC

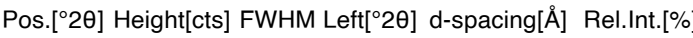

\begin{tabular}{ccccc}
\hline 25.2589 & 1233.20 & 8.7438 & 3.52305 & 100.00 \\
43.5468 & 384.92 & 4.5991 & 2.07663 & 31.21 \\
\hline
\end{tabular}

Table 3: XRD measurements of $\mathrm{Ni}^{2+} / \mathrm{HA}-\mathrm{ANC}$

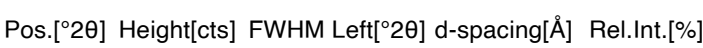

\begin{tabular}{lcccc}
\hline 5.0131 & 23772.90 & 0.0520 & 17.61333 & 100.00 \\
20.3762 & 708.42 & 3.3002 & 4.35492 & 2.98 \\
23.8854 & 1206.41 & 5.9034 & 3.72244 & 5.07 \\
26.5138 & 209.24 & 9.0362 & 3.35909 & 0.88 \\
42.5192 & 718.56 & 0.9656 & 2.12441 & 3.02 \\
\hline
\end{tabular}

SEM images have been used for morphological study of HA-ANC. The SEM 
micrographs of HA-ANC before and after adsorption of $\mathrm{Ni}^{2+}$ ions are shown in Fig. 5 and Fig. 6 respectively. In the SEM image of HA-ANC, the porous structure is obvious, but in the case of the used particles, the pores have been covered by the $\mathrm{Ni}^{2+}$ ions ${ }^{20,21}$.

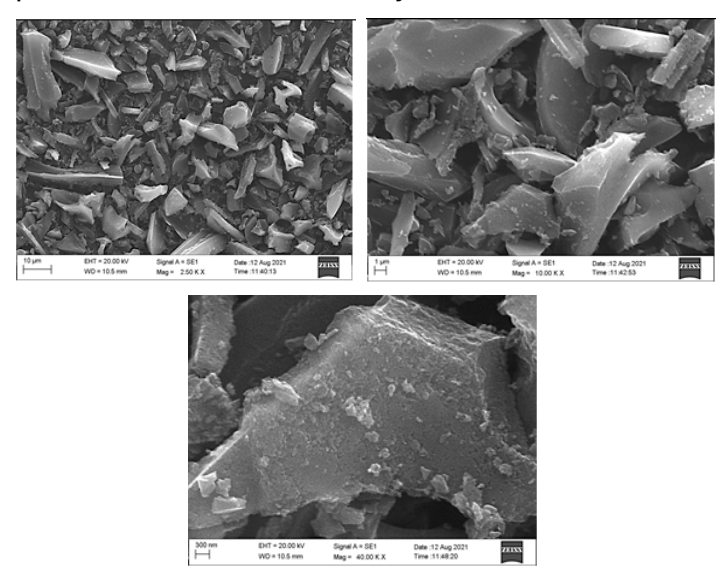

Fig. 5. SEM image for HA-ANC in different magnifications $10 \mu \mathrm{m}, 1 \mu \mathrm{m}$ and $300 \mathrm{~nm}$

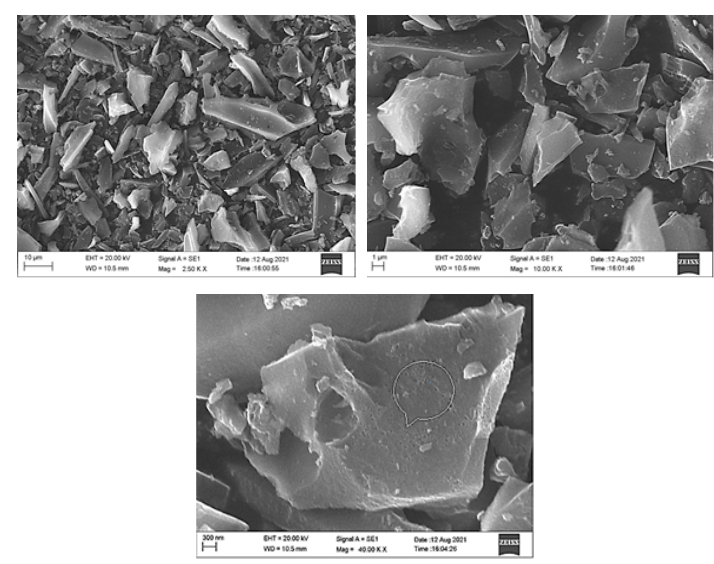

Fig. 6. SEM image for $\mathrm{Ni}^{2+} / \mathrm{HA}-\mathrm{ANC}$ in different magnifications $10 \mu \mathrm{m}, 1 \mu \mathrm{m}$ and $300 \mathrm{~nm}$

The EDX spectrum 22,23 of HA-ANC before and after adsorption of $\mathrm{Ni}^{2+}$ ions were evaluated shown in Fig. 7 and Fig. 8 respectively. The spectrum clearly indicates the peak of element $\mathrm{C}$, there was significant reduction in the intensity of peak of $\mathrm{C}$ in the after adsorption of $\mathrm{Ni}^{2+}$ ions comparing with the before adsorption. And also the peak of $\mathrm{Ni}^{2+}$ ions was notable on the after adsorption of $\mathrm{Ni}^{2+}$ ions onto $\mathrm{HA}$ ANC in addition the elemental compositions statistics were given in Table 4 and Table 5 respectively for before and after adsorption $\mathrm{Ni}^{2+}$ ions onto HA-ANC. In addition the atomic percentage of carbon reduced form $99.7 \%$ to $88.8 \%$ bassed on Table 4 and Table 5 , it can be usable as remarkable reduction.

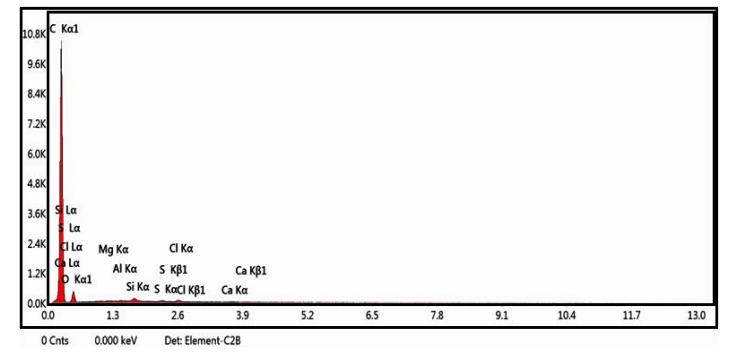

Fig. 7. EDX for HA-ANC

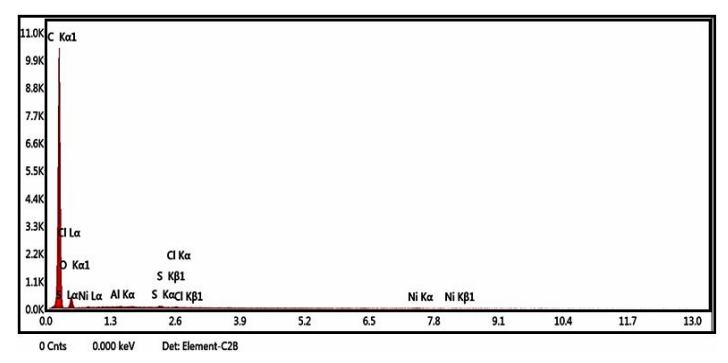

Fig. 8. EDX for $\mathrm{Ni}^{2+} / \mathrm{HA}-\mathrm{ANC}$

Table 4: EDX of Smart Quant Results for HA-ANC

\begin{tabular}{ccccc}
\hline Element & Weight\% & Atomic\% & Error\% & Kratio \\
\hline CK & 85.6 & 89.7 & 4.4 & 0.5959 \\
OK & 11.7 & 9.2 & 13.9 & 0.0133 \\
MgK & 0.5 & 0.2 & 13.2 & 0.0029 \\
AlK & 0.4 & 0.2 & 13.2 & 0.0026 \\
SiK & 0.7 & 0.3 & 7.2 & 0.0056 \\
SK & 0.3 & 0.1 & 18.3 & 0.0028 \\
CIK & 0.4 & 0.1 & 19.9 & 0.0035 \\
CaK & 0.4 & 0.1 & 27.7 & 0.0034 \\
\hline
\end{tabular}

Table 5: EDX of Smart Quant Results for $\mathrm{Ni}^{2+} / \mathrm{HA}$-ANC

\begin{tabular}{ccccc}
\hline Element & Weight $\%$ & Atomic\% & Error\% & Kratio \\
\hline CK & 84.8 & 88.8 & 4.0 & 0.6254 \\
OK & 13.5 & 10.6 & 13.6 & 0.0158 \\
AlK & 0.4 & 0.2 & 9.9 & 0.0031 \\
SK & 0.4 & 0.2 & 15.4 & 0.0038 \\
CIK & 0.2 & 0.1 & 30.2 & 0.0020 \\
NiK & 0.6 & 0.1 & 20.0 & 0.0062 \\
\hline
\end{tabular}

\section{CONCLUSION}

The Hygrophila auriculata activated nano carbon (HA-ANC) has been used successfully with an initial concentration of 10ppm at pH 6 in 60 minutes. The appearance, disappearance and shifting of peaks in the FT-IR spectrum confirmed the adsorption of $\mathrm{Ni}^{2+}$ ions onto HA-ANC as well as XRD analysis also provided reasonable evidence for adsorption to the adsorbent. In addition to supporting, the SEM study gives difference in the 
surface morphology of the adsorbent before and after the adsorption of $\mathrm{Ni}^{2+}$ ions as well as EDX also given elemental composition evident of removal of $\mathrm{Ni}^{2+}$ ions onto HA-ANC. Finally, it was concluded that the present adsorbent HA-ANC could be a good alternative adsorbent for the removal of heavy metals from aqueous solutions in a very efficient and economical manner.

\section{ACKNOWLEDGEMENT}

The authors sincerely thank the Government of Tamil Nadu Adi Dravidar and Tribal Welfare Department for providing the fund from Full Time Ph. D Scholars incentive Scheme.

\section{Conflict of interest}

The author declare that we have no conflict of interest.

\section{REFERENCES}

1. Mousa WM.; Soliman SI.; El-Bialy AB.; Hanaa A Shier. Journal of Applied Sciences Research., 2013, 9(3), 1696-170.

2. Pandharipande SL.; Rohit P.; Kalnake P. International Journal of Engineering Sciences \& Emerging Technologies., 2013, 4(2), 83-89.

3. Babel S.; Kurniawan TA. Journal of Hazardous Materials., 2003, 97, 219-243.

4. Figoli A.; Cassano A.; Criscuoli A.; Mozumder MSI.; Uddin MT.; Islam MA.; Driolo E. Water Research., 2010, 44, 97-104.

5. ArivoliS.; VenkatramanBR.; Rajachandrasekar T.; Hema M. Research Journal of Chemistry and Environment., 2007, 17, 70-78.

6. Arivoli S.; Kalpana K.; Sudha R.; Rajachand rasekar T. E-Journal of Chemistry., 2007; 4, 238-254.

7. Coogan TP.; Latta DM.; Snow ET.; Costa M.; Lawrence A. Critical Reviews in Toxicology., 1989, 19, 341-384.

8. Savolainen H. Reviews on environmental health., 1996, 11, 167-173.

9. Arivoli S.; Hema M.; Parthasarathy S.; Manju N. Journal of Chemical and Pharmaceutical Research., 2010, 2(5), 626-641.

10. Arivoli S.; Hema M. International Journal of Physical Sciences., 2007, 2, 10-17.

11. Nhamo Chaukura.; Edna C. Murimba.; Willis Gwenzi, Applied Water Science., 2017, 7, 2175-2186.

12. Chantakorn Patawat, Ketsara Silakate, Somchai Chuan-Udom, Nontipa Supan chaiyamat, Andrew J. Hunt, Yuvarat Ngernyen, RSC Advances., 2020, 10, 21082 -21091.
13. Arivoli S.; Viji Jain M.; Rajachandrasekar T. Material Science Research India., 2006, 3, 241-250.

14. El-Sadaawy M.; Abdelwahab O.; Alexandria Engineering Journal., 2014, 53(2), 399-408.

15. Gonzalez JF.; Silvia R.; Gonzalez G.; Carmen M.; Nabais JM.; Valente.; Luis OA. Industrial \& Engineering Chemistry Research., 2009, 48, 7474-7481.

16. Muniandy L.; Adam F.; Mohamed AR.; E-P Ng. Microporous and Mesoporous Materials., 2014, 197, 316-323.

17. Pavan Kumar GVSR.; Komal Avinash Malla.; Bharath Yerra.; Srinivasa Rao K, Applied Water Science., 2019, 9(3), 44,1-9.

18. Qu D. Journal of Power Sources., 2002, 109, 403-411.

19. Bratek W.; Świą tkowski A.; Pakuła M.; Biniak S.; Bystrzejewski.; Szmigielski R, Journal of Analytical and Applied Pyrolysis., 2013, 100, 192-198.

20. El-Araby H.A.; Ibrahim AMMA.; Mangood AH.; Abdel-Rahman AAH, Journal of Geoscience and Environment Protection., 2017, 5, 109-152.

21. Gil R R.; Ruiz B.; Lozano MS.; Fuente E, Journal of Analytical and Applied Pyrolysis., 2014, 110(1), 194-204.

22. Agegnehu Alemu.; Brook Lemma.; Nigus Gabbiye.; Melisew Tadele Alula.; Minyahl Teferi Desta. Heliyon., 2018, 4(e00682), 1-22.

23. Xie Youping.; Li Hang.; Wang Xiaowei.; $\mathrm{Ng}$ I-Son.; Lu Yinghua.; Jing Keju. Journal of the Taiwan Institute of Chemical Engineers., 2014, 45(4), 1773-1782. 